\title{
Host plants of pentatomids affecting rice fields in Puerto Rico'
}

\author{
Rosa A. Franqui, Alberto Pantoja, Silverio Medina-Gaud ${ }^{2}$
}

\begin{abstract}
A host plant survey for rice stinkbugs was condueted on commercial rice fields in Puerto Rico. Alternate host plants for the five stinkbug species consistently collected from rice fields were identified. Ten plant species were identified as alternate host plants. Oebalus pugnax (F.) displayed the narrowest host range and was collected only from Sorghum bicolor (L.) Moench and Sorghum halepense (L,) Pers. The two most abundant stinkbug species, Mormidea angustafa Stål and Oebalus ypsilon-griseus (De Geer), exhibited a similar preference or host plant range. Nearly twice as many stinkbugs were collected from weedy fields (560 insects) than from weedfree fields ( 362 insects).
\end{abstract}

\section{RESUMEN}

Plantas hospederas de los pentatómidos de los arrozales de Puerto Rico

Un estudio de plantas hospederas de chinches apestosas se realiź́ en arrozales comerciales de Puerto Rico. Se identificaron los hospederos alternos de cinco especies de pentatómidos presentes en los arrozales. Diez plantas se identificaron como hospederas alternas. Oebalus pugnax ( $F$.) fue el que menos hospederos fuvo, ya que solo se colectó en Sorghum bicolor (L.) Moench y Sorghum halepense (L.) Pers. Las dos especies de chinches apestosas más abundantes, Mormidea angustata Siàl y Oebalus ypsilon-griseus (De Geer), tuvieron un rango similar de hospederos. En promedio, se coleccionaron casi dos veces más chinches en arrozales infestados con yerbajos (560) que en arrozales sin yerbajos (362).

\section{INTRODUCTION}

The importance of alternate hosts in the development of stinkbug populations on rice has been studied by Bowling (1), Ingram (4), Douglas and Ingram (3), Kennard (6), and Pathak (9). In Puerto Rico five stinkbugs species, Mormidea angustata Stål, Mormidea cubrosa Dallas, Oebalus grisescens Sailer, Oebalus pugnax (F.), and Oebalus ypsilongriseus (De Geer) have been associated with rice fields. The pest status, alternate hosts and seasonal abundance of these five stinkbug species recovered from Puerto Rico rice fields are still unknown.

'Manuseript submitted to Editorial Board 1 February 1988.

${ }^{2}$ Research assistant, Assistant Entomologist and Entomologist, Dept. Crop Protection, Agricultural Experiment Station, College of Agricultural Seiences, University of Puerto Rico, Rio Piedras, P. R. This research was supported by the Puerto Rico Agricultural Experiment Station and CSRS Grant 85-CRSR-2-2621. 
The seasonal occurrence of $O$. pugnax in rice fields has been studied by Douglas (2), Odglen and Warren (8), and Jones and Cherry (5). Injurious stinkbug populations develop on grasses in the field and nearby areas and migrate to rice plants later during the season $(3,4,6)$. As the grain hardens and the crop approaches maturity, the insects move to younger rice fields, or to wild grasses (6). Migration from adjacent habitats is considered an important factor in the development of injurious $O$. pugnax populations in Texas rice fields (1).

Despite the importance of alternate hosts in the development of injurious stinkbug populations on rice fields, little is known about the wild hosts of pentatomids affecting rice in Puerto Rico. Wolcott (11) collected $M$. angustata and $M$. cubrosa from weeds and leguminous plants in the western part of Puerto Rico, but the plant species were not reported. According to Martorell (7) Crotalaria retusa L., Dioscorea sp. and Pisum sativum L. serve as hosts for $M$. angustata. Gossypium barbadense $\mathrm{L}$. is the only alternate host reported for $M$. cubrosa in Puerto Rico (7). The objectives of the research reported here were to identify the alternate hosts of the five stinkbugs consistently collected from Puerto Rico rice fields and assess their abundance in weed-free and weedy fields.

\section{MATERIALS AND METHODS}

A host plant survey was conducted at commercial rice fields in Vega Baja. Insects were observed from a distance $(1$ to $1.5 \mathrm{~m})$ to determine if the plant served as food, shelter, oviposition site or more than one of these alternatives. Observations were made early in the morning ( 900 h), at $(1200 \mathrm{~h})$ noon, and late in the afternoon $(1600 \mathrm{~h})$. Plants on which pentatomids were observed were collected and preserved for identification. Collected plants were identified by $\mathrm{H}$. A. Liogier (Plant Taxonomist, Botanical Garden, University of Puerto Rico, Río Piedras, Puerto Rico).

In a separate study, adult pentatomids and nymphs were collected to determine the relative abundance of stinkbugs on clean (no weeds) and weedy fields. All samples were collected at Vega Baja, Puerto Rico, from June to September. A total of 160 samples (10 samples per week; 5 from weedy fields, 5 from clean fields) were collected. Each field was sampled weekly with a standard insect net ( $38.1 \mathrm{~cm}$ diameter). Each sample consisted of 100 sweeps randomly collected. Each horizontal stroke with the net in either direction was considered as one sweep. One sweep was made with each forward step. Sampling began at least $10 \mathrm{~m}$ into the field, from the roadside, and was centered between the field levees to avoid possible edge effects $(2,5)$. 


\section{RESULTS AND DISCUSSION}

Ten plant species were identified as alternate hosts for the five stinkbug species consistently collected from rice fields in Puerto Rico (table 1). Nine belong to Gramineae family and one, Cyperus iria L., to the Cyperaceae. The lack of broadleaf weeds in table 1 is the result of propanil applications which selectively control these weeds. It is not known how the insects will behave in the presence of broadleaf alternate hosts because propanil application is a common practice among rice farmers.

All stinkbug species, except $O$. pugnax, were collected or observed feeding on C. iria. Oebalus pugnax, displayed the narrowest host range and was collected from only two plant species, Sorghum bicolor (L.) Moench and Sorghum halepense (L.) Pers. Both, S. bicolor and S. halepense have been reported as alternate hosts of $O$. pugnax (10). It is not known why $O$. pugnax was not collected from the other plant species listed in table 1, although they were readily available during the study period.

The two more abundant stinkbug species, $M$. angustata and $O$. ypsilon-griseus, exhibited a similar preference or host plant range. Both stinkbug species were collected from all plant species except $S$. bicolor. Digitaria ciliaris (Retz.) Koeler served as alternate host for $O$. ypsilongriseus, but not for $M$. angustata. Oebalus grisescens was not seen or collected on any of the three Digitaria species commonly observed on

TABLE 1.-Host plants for five pentatomid species affecting rice fields in Puerto Rico, 1986

\begin{tabular}{|c|c|c|c|c|c|}
\hline \multirow[b]{2}{*}{ Host plant (Family/species) } & \multicolumn{5}{|c|}{ Insect species' } \\
\hline & M.a. & M.e. & $0 . y-g$ & O.p. & $0 . g$ \\
\hline Cyperacae Cyperus iria L. & $\mathrm{X}^{2}$ & $\mathrm{X}$ & $\mathrm{X}$ & - & $x$ \\
\hline Gramineae & & & & & \\
\hline Digitaria bicornis (Lam.) Roem. \& Schult & $\mathrm{X}$ & - & $\mathrm{X}$ & - & - \\
\hline Digitaria ciliaris (Retz.) Koeler & - & - & $\mathrm{X}$ & - & - \\
\hline Digitaria sanguinalis (L.) Scop. & $\mathbf{X}$ & - & $\mathrm{X}$ & - & - \\
\hline Echinochloa colona (L.) Link & $\mathrm{X}$ & $\mathrm{X}$ & $\mathrm{X}$ & - & $\mathrm{X}$ \\
\hline Eriochloa puntacta (L.) Desv. & $\mathrm{X}$ & $\mathrm{X}$ & $\mathrm{x}$ & - & $\mathrm{X}$ \\
\hline Eleusine indica (L.) Gaertn. & $\mathrm{X}$ & $\mathrm{X}$ & $\mathrm{X}$ & - & $\mathrm{X}$ \\
\hline Panicum muticum Forsk. & $\mathrm{X}$ & - & $\mathrm{X}$ & - & $\mathrm{X}$ \\
\hline Sorghum bicolor (L.) Moench & - & - & - & $\mathrm{X}$ & - \\
\hline Sorghtm halepense (L.) Pers. & $\mathrm{X}$ & - & $\mathrm{x}$ & $\mathrm{X}$ & $\mathrm{X}$ \\
\hline
\end{tabular}

${ }^{1}$ M.a. = Mormidea angustata

M.c. = Mormidea cubrosa

O.g. - Oebalus grisescens

o.p. = Debalus pugnax

O.y-g. $=$ Oebalus $y$ psilon-grisers

${ }^{2} \mathrm{X}$ indicates host plant; - indicates non-host plant. 
rice fields; thus, apparently this plant species is not a preferred host for O. grisescens.

Mormidea cubrosa exhibited the narrowest host range collected from four plant species: C. iria, Echinocloa colona (L.) Link, Eriochloa punetata L. Desv., and Eleusine indica (L.) Gaertn. Mormidea cubrosa was observed feeding on $C$. iria and $E$. colona within rice fields, but seldom feeding on rice panicles.

Nearly twice as many stinkbugs were collected from weedy fields (560.2 insects) than from weed-free fields (362.2 insects, table 2$)$. These results are in accordance with previous reports $(4,6,10)$ indicating that injurious stinkbug populations develop on weeds and migrate to rice fields later during the season. These results emphasize the importance of weed control programs in controlling stinkbug populations on rice fields in Puerto Rico.

Oebalus ypsilon-griseus was the most abundant species, and also the only species with almost equal abundance on weedy (295.3 insects per 100 sweeps) and weed-free fields (274.2 insects per 100 sweeps). The data suggest that 0 . ypsilon-griseus may be developing on rice fields and not migrating from nearby weeds. Smith et al. (10) reported the development of four generations of $O$. pugnax in Louisiana rice fields. The first. two generations develop on weeds; the last two generations, (called resident generation), originated from migratory 0 . pugnax, but developed on rice.

During the early morning $M$. angustata, $O$. ypsilon-griseus and $O$. grisescens were observed on the lower parts of the plants, near the soil surface in areas of high weed density and thick canopy such as that provided by Panicum muticum Forsk. Thick canopy plants provide shelter and protection against predators, heat and desiccation, Later during the day, the insects move to the upper parts of the plants and panicles and could be observed mating and moving from plant to plant. Farmers usually apply insecticides during the early hours of the morning (600-800

TabLe 2.-Mean number of Mormidea angustata Stål, Mormidea cubrosa Dallas, Oebalus grisescens and Oebalus ypsilon-gxiseus collected on weed-free and weedy rice fields.

Vega Baja, Puerto Rico, 1986

\begin{tabular}{lcc}
\hline & \multicolumn{2}{c}{ Meannumber of insects in } \\
\cline { 2 - 3 } \multicolumn{1}{c}{ Species } & Weed-ree & Weedy \\
\hline Mormidea angustata & 60.6 & 120.7 \\
Mormidea cubrosa & 2.2 & 4.0 \\
Oebalus ypsilon-griseus & 274.2 & 295.3 \\
Oebalus grisescens & 25.2 & 140.3 \\
\multicolumn{1}{c}{ Total } & 362.2 & 560.3 \\
\hline
\end{tabular}

Means represent number of insects per 100 sweeps. 
h). At this time insects are protected inside the lower parts of the plant and are not fully exposed to the insecticide.

Insects were observed mating at all times during the day (except during the early hours of the morning) and in all host plants. Insecticide applications and scouting during the late evening will be more effective as insects are actively mating and feeding on the panicles.

Oviposition was recorded only for Oebalus ypsilon-griseus and $M$. angustata. Preliminary data showed a preference for rice panicles rather than foliage or stems for oviposition. Oviposition was not recorded on any of the weed species on which the insects were observed.

All species displayed a preference for weedy fields as compared to clean rice fields (table 2). Probably the abundance of weeds within the field attracted more $M$. angustata and $O$, grisescens. Oebalus ypsilongriseus ovipositional preference for rice panicles probably accounted for the similar insect population on rice and weeds (table 2).

Information provided here will benefit field survey personnel, since sampling sites and times for stinkbug adults and eggs on rice fields have now been determined. This study provides important and new information on stinkbug alternate host plants. To our knowledge this is the first report of $M$. angustata, $M$. cubrosa, $O$.ypsilon-griseus and $O$.grisescens alternate hosts in Puerto Rico rice fields.

Additional studies are needed to determine the effects of weed control on the development of injurious stinkbug populations and to study the host preference of the five pentatomid species in our study. Research is also needed to study the life cycle and pest status of the local stinkbug populations.

\section{LITERATURE CITED}

1. Bowling, C. C., 1962. Effect of insecticides on rice stinkbug populations. $J$, Econ. Entomol. 55: 648-51.

2. Douglas, W. A, 1939. Studies of rice stinkbug with special reference to local migration. J. Econ. Entomol. 33: 300-03.

3. - _ and J. W. Ingram, 1942. Rice field insects. U. S. Dep. Agric. Circ. 632: 2-7.

4. Ingram, J. W., 1927. Insects injurious to the rice crop. U. S. Dep. Agric. Farmers Bull. 1543: 1-4.

5. Jones, D. B. and R. H. Cherry, 1986. Species composition and seasonal abundance of stinkbugs (Heteroptera:Pentatomidae) in southern Florida rice. J. Econ. Entomol. 79: 1226-229.

6. Kennard, C. P., 1965. FAO Plant Prot. Bull. 13 (4); 73-8.

7. Martorell, L. F., 1976. Annotated food plant eatalog of the insects of Puerto Rico. Agric. Exp. Stn., Univ. P. R.

8. Odglen, G. E, and L. D. Warren, 1962. The rice stinkbug Oebalas pugnax (F.) in Arkansas. Arkansas Agric. Exp. Stn. Rep. Ser. No. 107. (Abst.)

9. Pathak, M. D., 1968. Ecology of common insects pests on rice. Ann. Rov. Entomol. 13: $257-94$.

10. Smith, C. M., J. L. Bagent, S. D. Liscombe and J. F. Robinson, 1986. Insect pests of rice in Louisiana. La. Agric. Stn. Bull. 774.

11. Woleott, G. N., 1948. The insects of Puerto Rico. I. Agrie. Univ. P. R. 32: 77-8. 
